\title{
2-Hydroxy-4,6-dimethoxyacetophenone from Leaves of Peperomia glabella
}

\author{
Marisi G. Soares, ${ }^{a}$ Ana P. V. de Felippe, ${ }^{a}$ Elsie F. Guimarães, ${ }^{a}$ Massuo J. Kato, ${ }^{a}$ Javier Ellena ${ }^{b}$ \\ and Antonio C. Doriguetto ${ }^{*, c}$ \\ ${ }^{a}$ Instituto de Química, Universidade de São Paulo, Av. Prof. Lineu Prestes, 748, Cidade Universitária, \\ 05508-900 São Paulo-SP, Brazil \\ ${ }^{b}$ Instituto de Física de São Carlos, Universidade de São Paulo, CP 369, 13560-970 São Carlos-SP, Brazil \\ ${ }^{c}$ Departamento de Ciências Exatas, Universidade Federal de Alfenas, 37130-000 Alfenas-MG, Brazil
}

\begin{abstract}
A 2-hidroxi-4,6-dimetoxiacetofenona foi isolada de folhas de Peperomia glabella (família Piperaceae). A substância cristaliza no grupo espacial P $\overline{1}$ com duas moléculas na unidade assimétrica. A análise estrutural revela uma rede bidimensional infinita no plano (011), estabilizada por ligações de hidrogênio inter-moleculares ao longo da direção [100] e interações de van der Waals ao longo da direção [011]. As moléculas apresentam fortes ligações de hidrogênio intra-moleculares $[\mathrm{O} 1-\mathrm{HO} 1 \ldots \mathrm{O} 4=1,53(2) \AA$ e O5-HO5...O8 = 1,38(2) $\AA$ ] . A conformação molecular foi analisada usando o MOGUL, uma base de dados de geometria molecular derivada do CSD (Cambridge Structural Database).
\end{abstract}

The 2-hydroxy-4,6-dimethoxyacetophenone was isolated from the leaves of the Peperomia glabella (Piperaceae family). The molecule crystallizes in the space group $\mathrm{P} \overline{1}$ with two independent molecules in the asymmetric unit. The structural analysis reveals an infinite twodimensional network in the (011) plane, stabilized by intermolecular hydrogen bonds along [100] and van der Waals interactions along [011]. The molecules present strong intra-molecular hydrogen bonds [O1-HO1...O4 = 1.53(2) $\AA$ and O5-HO5...O8 = 1.38(2) $\AA$ ]. The molecular conformation was analyzed using the MOGUL, a knowledge base of molecular geometry derived from the CSD (Cambridge Structural Database).

Keywords: Peperomia glabella, 2-hydroxy-4,6-dimethoxyacetophenone, X-ray diffraction

\section{Introduction}

Peperomia glabella (Piperaceae) is an epiphyte used in Venezuelan folk medicine as an antiasthmatic. ${ }^{1}$ Piperaceae family comprises 14 genera and 1950 species. ${ }^{2}$ Among these, Piper and Peperomia are the most abundant with approximately 700 and 600 species, respectively. ${ }^{3}$ Phytochemical profile from genus Piper is characterized by occurrence of lignans and neolignans, ${ }^{4,5}$ chromenes, ${ }^{6-8}$ amides, ${ }^{9,10}$ alkaloids, ${ }^{11}$ Phenylpropanoids, ${ }^{12}$ and cyclopentenedione derivatives. ${ }^{13}$ Comparative study showed divergence of secondary metabolism in cell suspension cultures and differentiated plants of $P$. cernuum and P.crassinervium. ${ }^{14}$ Compared with the genus Piper, few chemical investigations reported so far for Peperomia species have shown their common constituents as phenylpropanoids, benzopyrans, chromenes, and prenylated hydroquinones. ${ }^{15-17}$ Additionally

*e-mail: doriguetto@unifal-mg.edu.br there are several nor/seco-compounds, e.g., the cyclobutane compound from Peperomia pellucida that seems to be produced by dimerisation of styryl phenol (a norphenylpropanoid). ${ }^{18} P$. glabella has been shown to contain one secolignan of butenolide skeleton. ${ }^{19}$ In this work we wish to report the structure of the 2-hydroxy-4,6-dimethoxyacetophenone, (1), extracted from leaves of Peperomia glabella. Acetophenone derivatives have shown many interesting biological properties such as antinflammatory, ${ }^{20,21}$ cytotoxic, ${ }^{22}$ and choleretic ${ }^{23}$ activities. This compound was previously isolated from Artemisia maritima, ${ }^{24}$ Artemisia gypsaceae, ${ }^{25}$ and Plagiochila fasciculata showing antifungal activities against Trichophyton mentagrophytes ${ }^{26}$ from strain of Trichoderma pseudokoningii Rifai. ${ }^{27}$ It is important to emphasize that (1) can be also obtained by synthetic route, from different starting compound, such as 1-hydroxy-3,5dimethoxybenzene, ${ }^{28,29}$ 2,4,6-trihydroxiacetophenone, ${ }^{30}$ and 1,3,5-trihydroxybenzene. ${ }^{31}$ 
<smiles>COc1cc(O)c(C(C)=O)c(OC)c1</smiles>

The aim of the present work is to determine unambiguously the molecular structure of (1) by X-ray diffraction (XRD) and its intra and inter-molecular geometry as well. To the best of our knowledge, this is the first occurrence of this class of compound in Peperomia species.

\section{Experimental}

\section{General Considerations}

The compound was isolated from leaves of samples of Peperomia glabella. All chemicals used during the extraction, purification and crystallization were of analytical or chromatography grade.

${ }^{1} \mathrm{H}$ and ${ }^{13} \mathrm{C}$ NMR spectra (4.9 T) were recorded on a Bruker AC-200 spectrometer operating at room temperature, using tetramethylsilane as an internal reference.

Plant material, extraction and isolation of 2-hydroxy-4,6dimethoxyacetophenone

Peperomia glabella samples were collected at Lençóis (12 45' 19.5" S 41 30' 34.1" W) Bahia, Brazil. The leaves $(8.20 \mathrm{~g})$ were extracted four times with methanol $(300 \mathrm{~mL}$ each time) at room temperature. This extract $(2.07 \mathrm{~g})$ was submitted to normal-phase silica gel column chromatography using increasing proportions of hexane: $\mathrm{CH}_{2} \mathrm{Cl}_{2}$. 2-hydroxy4,6-dimethoxyacetophenone was obtained as solid white, 172 $\mathrm{mg}$, crystallized from $\mathrm{CH}_{3} \mathrm{OH}: \mathrm{CH}_{2} \mathrm{Cl}_{2}$.

\section{Identification of 2-hydroxy-4,6-dimethoxyacetophenone}

The ${ }^{1} \mathrm{H}$ NMR spectrum of (1) showed two aromatic meta hydrogens at $\delta 6.05$ and $5.93(\mathrm{~d}, J 2.2 \mathrm{~Hz}$ ). In addition, the acetophenone group was inferred from the methyl group at $\delta 2.60$ and confirmed by ${ }^{13} \mathrm{C}$ NMR spectrum at $\delta 32.7$ and by acetophenone carbonyl at $\delta$ 203.5. The additional substituents of the aromatic ring were defined as one quelated hydroxyl at $\delta 11.20$ and two methoxyls observed at $\delta 3.85(\delta$ 55.4) and $\delta 3.81$ $\left(\delta\right.$ 55.4). The ${ }^{13} \mathrm{C}$ NMR spectrum (4.9 T) showed signals corresponding to four aromatic carbon quaternary atoms ( $\delta 105.8 ; 167.5 ; 166.0$; and 162.7); and two aromatic methyne ( $\delta 90.6$ and 93.0). Thus, compound (1) was identified as 2-hydroxy-4,6-dimethoxyacetophenone. ${ }^{24}$

\section{X-ray Structure analysis of 2-hydroxy-4,6-dimethoxyaceto-} phenone

A well-shaped single crystal of (1) was selected for the XRD experiments. The intensity data were collected at $150 \mathrm{~K}$ on an Enraf-Nonius Kappa-CCD diffractometer (95 mm CCD camera on $\mathrm{k}$-goniostat) with graphite monochromated Mo $\mathrm{K} \alpha(\lambda=0.71073 \AA)$ radiation. The temperature was controlled using an Oxford Cryosystem low temperature device. Data collection ( $\varphi$ scans and $\omega$ scans with $\kappa$ offsets) was made using the COLLECT; ${ }^{32}$ integration and scaling of the reflections were performed with the HKL Denzo-Scalepack system of programs. ${ }^{33}$ The final unit cell parameters were based on all reflections using HKL Scalepack. ${ }^{33}$ The structure was solved using Direct Methods with SHELXS-97. ${ }^{34}$ The model was refined by full-matrix least-squares procedures on $\mathrm{F}^{2}$ using SHELXL$97 .{ }^{34} \mathrm{H}$ atoms of the phenyl and methyl groups were positioned stereochemically and were refined with fixed individual displacement parameters $\left[\mathrm{U}_{\text {iso }}(\mathrm{H})=\right.$ $1.2 \mathrm{U}_{\text {eq }}\left(\mathrm{C}_{\text {aromatic }}\right)$ or $\left.1.5 \mathrm{U}_{\text {eq }}\left(\mathrm{C}_{\text {methoxy }}\right)\right]$ using a riding model, with aromatic C-H distances of $0.95 \AA$ and methyl C-H distances of $0.98 \AA$. The two hydroxyl $\mathrm{H}$ atoms were located by difference Fourier synthesis and were set as isotropic.

Data collections and experimental details for (1) are summarized in Table 1. The programs SHELXL-97, SHELXS-97, and ORTEP- $3^{35}$ were used within WinGX ${ }^{36}$ to prepare materials for publication. The programs Mercury $^{37}$ and ORTEP-3 were used to prepare the molecular graphics.

\section{Results and Discussion}

Figure 1 shows an ORTEP- $3^{35}$ view of (1) with the atom numbering scheme. The structure crystallizes in $\mathrm{P} \overline{1}$ with two independent molecules in the asymmetric unit (labelled as A and B in Figure 1). Comparison of these molecules by the method of Kabsch ${ }^{38}$ showed them to be very similar with a root mean square deviation between homologous atoms of $0.024 \AA$. This fact suggested that the crystal could belong to a higher symmetric space group with just one molecule per asymmetric unit. Closer scrutiny, however, showed this is not the case because the affin transformation relating the two moieties did not coincide with any of those belonging to other space group. This symmetry was also carefully 
Table 1. Crystal data, data collection details and structure refinement results of $\mathbf{1}$

\begin{tabular}{lll}
\hline Empirical formula & $\mathrm{C}_{10} \mathrm{H}_{12} \mathrm{O}_{4}$ \\
Formula weight & 392.39 \\
Crystal system & Triclinic \\
Space group & $\mathrm{P} \overline{1}(\mathrm{No} .2)$ & \\
Unit cell dimensions $(\AA))^{\circ}$ & & \\
& $\alpha=8.0551(4) \quad \quad \alpha=70.590(3)$ \\
& $\beta=11.5505(6) \quad \beta=77.218(3)$ \\
& $\gamma=11.7068(6) \quad \gamma=75.733(3)$ \\
Volume $\left(\AA^{3}\right)$ & $983.98(9)$ & \\
$Z$ & 4 & 1.122 \\
Density (calculated) $\left(\mathrm{mg} \mathrm{m}^{-3}\right)$ & 0.103 \\
Absorption coefficient $\left(\mathrm{mm}^{-1}\right)$ & 416 \\
$F(000)$ & $0.05 \times 0.05 \times 0.2$ \\
Crystal size (mm $\left.{ }^{3}\right)$ & 2.95 to 25.00 \\
$\theta$ range for data collection $(\mathrm{deg})$ & $-9<=\mathrm{h}<=9,-13<=\mathrm{k}<=13,-13<=1<=13$ \\
Index ranges & 19598 \\
Reflection collected & $3461[\mathrm{R}(\mathrm{int})=0.0775]$ \\
Independent reflections & 99.7 \\
Completeness to $\theta=25.0^{\circ}(\%)$ & $\mathrm{None}$ \\
Absorption correction & $3461 / 0 / 260$ \\
Data/restraints/parameters & 0.998 \\
Goodness-of-fit on $F^{2}$ & $\mathrm{R} 1=0.0486, \mathrm{wR} 2=0.1154$ \\
Final $R$ indexes $[I>2 \sigma(I)]$ & $\mathrm{R} 1=0.0873, \mathrm{wR} 2=0.1380$ \\
$R$ indexes (all data) & $0.036(8)$ \\
Extinction coefficient & \\
Largest diff. peak and hole $\left(\mathrm{e} . \AA^{-3}\right)$ & 0.205 and -0.202 \\
\hline & & \\
\hline
\end{tabular}

examined using PLATON, ${ }^{39}$ and it was concluded that $\mathrm{P} \overline{1}$ is in fact the correct space group.

The main geometric parameters are given in Table 2 . The molecular conformation was analyzed using the MOGUL, ${ }^{40}$ a knowledge base of molecular geometry derived from the Cambridge Structural Database (CSD $)^{41}$ that provides rapid access to information on the preferred values of bond lengths, valence angles and acyclic torsion angles. The Figure 2 shows an example of the graphical result of the query molecule studied here (molecule A). The resulting histogram is the $\mathrm{C} 1-\mathrm{O} 1$ bond length comparing with the $\mathrm{C}-\mathrm{O}$ bond lengths in CSD entries containing similar structures. As emphasized by Bruno et al. ${ }^{40}$ comparison of the dimensions of a newly determined small-molecule crystal structure with bond lengths and angles of similar structures in the CSD is useful as a check against refinement errors and to highlight unusual geometrical features. This study showed that all bond lengths and bond angles are in agreement with the expected values for a good X-ray diffraction structure refinement. However, the MOGUL analysis has pointed out two interesting geometrical features due to resonance involving the moiety O3-C5-C6-C7-O4 (see Figure 1 and Table 2). It was observed that $\mathrm{C} 5-\mathrm{O} 3$ and $\mathrm{C} 6-\mathrm{C} 7$ is shorter than the average query values whereas the $\mathrm{C} 5-\mathrm{C} 6$ and $\mathrm{C} 7$ $\mathrm{O} 4$ is longer than the expected ones. It is important to emphasize that the same behaviour (not shown in Table 2) was observed to the molecule B present in the asymmetric unit.

Both molecules in the asymmetric unit are almost flat. The largest deviations from the least squares plane through the aromatic ring system $\mathrm{A}$ are -0.176(4) and 0.112(4) $\AA$ for C8 and C9 atoms, respectively. Similar results were observed to the molecule $\mathrm{B}$ : the largest

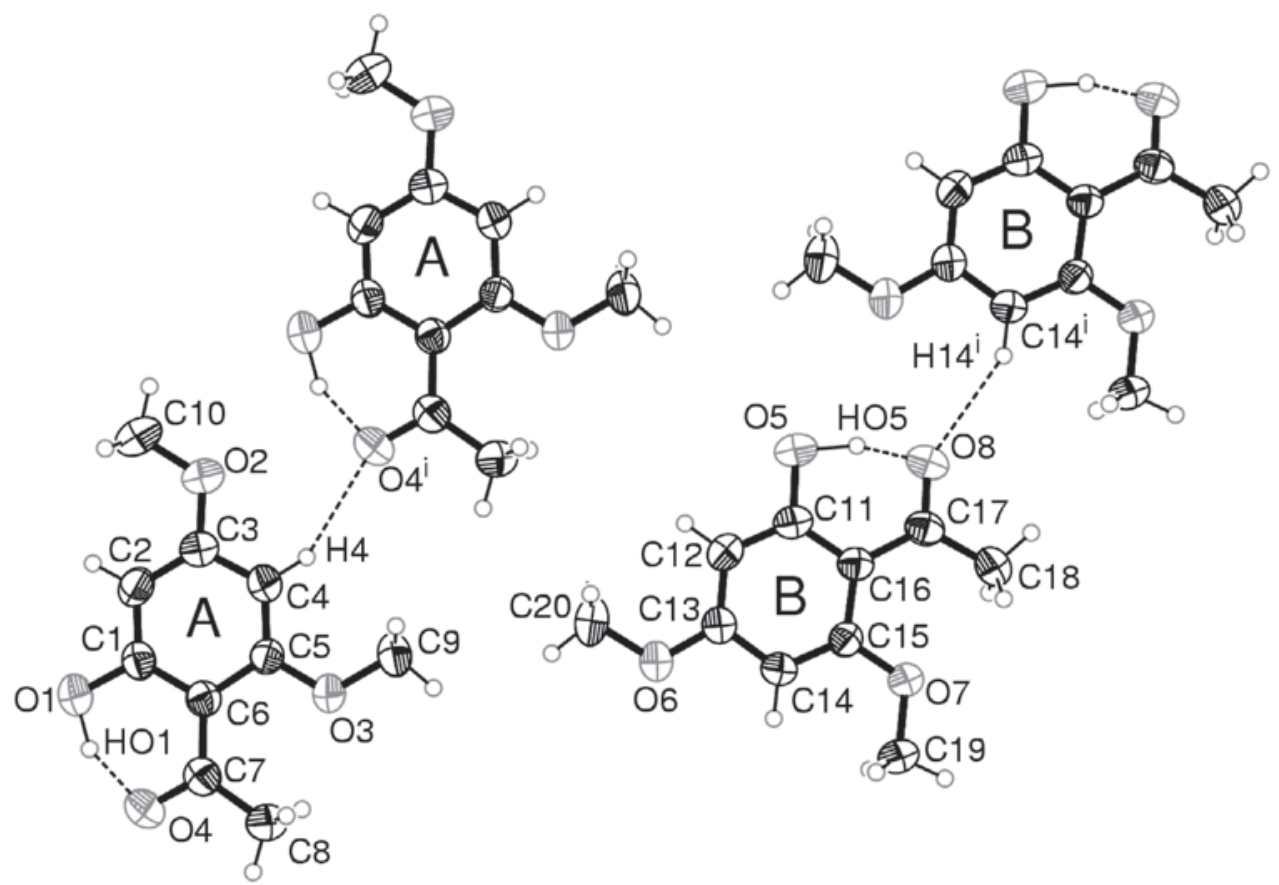

Figure 1. View of (1) with displacement ellipsoids for the non-hydrogen atoms shown at the 50\% probability level. The $\mathrm{H}$ atoms are shown as spheres of arbitrary radii. Hydrogen bonds are indicated by dashed lines. 


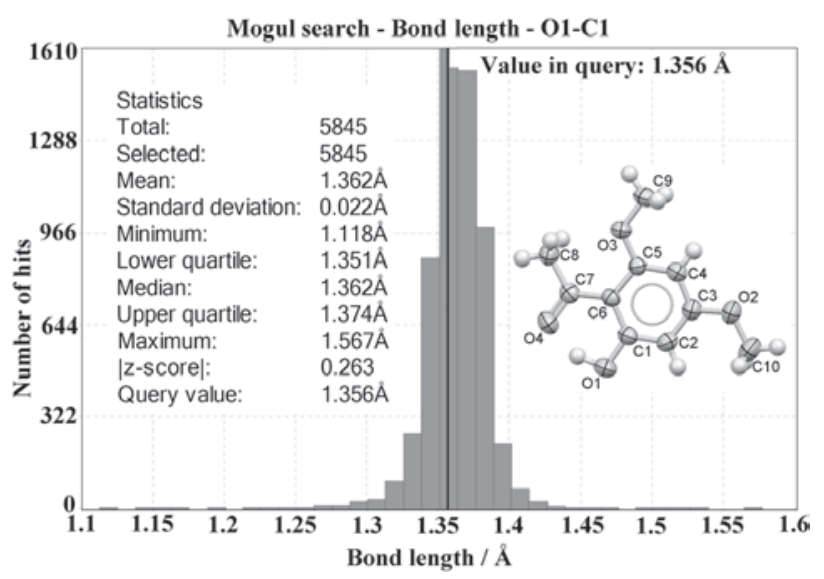

Figure 2. Histogram comparing the $\mathrm{C} 1-\mathrm{O} 1$ bond length with the $\mathrm{C}-\mathrm{O}$ bond lengths in CSD entries containing structures similar to 2-hydroxy4,6-dimethoxyacetophenone.

Table 2. Selected Bond lengths $(\AA)$ and angles $\left(^{\circ}\right)$ for compound $(\mathbf{1})$ and MOGUL bond analysis

\begin{tabular}{lccccc}
\hline $\begin{array}{l}\text { Geometry } \\
\text { Type }\end{array}$ & Bond & $\begin{array}{c}\text { Average } \\
\text { query }\end{array}$ & $\begin{array}{c}\text { Geometry } \\
\text { Type }\end{array}$ & Angle & $\begin{array}{c}\text { Average } \\
\text { query }\end{array}$ \\
\hline C1-O1 & $1.356(2)$ & $1.36(2)$ & O1-C1-C2 & $116.4(2)$ & $120(3)$ \\
C1-C2 & $1.384(3)$ & $1.38(2)$ & O1-C1-C6 & $121.2(2)$ & $121(2)$ \\
C1-C6 & $1.414(2)$ & $1.41(2)$ & C2-C1-C6 & $122.3(2)$ & $121(2)$ \\
C2-C3 & $1.384(3)$ & $1.38(2)$ & C1-C2-C3 & $118.9(2)$ & $119(2)$ \\
C3-O2 & $1.363(2)$ & $1.37(3)$ & O2-C3-C2 & $124.1(2)$ & $120(5)$ \\
C3-C4 & $1.388(3)$ & $1.38(2)$ & O2-C3-C4 & $114.8(2)$ & $120(5)$ \\
C4-C5 & $1.373(3)$ & $1.38(2)$ & C2-C3-C4 & $121.1(2)$ & $121(2)$ \\
C5-O3 & $1.351(2)$ & $1.37(2)$ & C5-C4-C3 & $119.8(2)$ & $118(2)$ \\
C5-C6 & $1.428(3)$ & $1.40(2)$ & O3-C5-C4 & $122.6(2)$ & $124(2)$ \\
C6-C7 & $1.455(3)$ & $1.49(3)$ & O3-C5-C6 & $115.7(2)$ & $116(2)$ \\
C7-O4 & $1.249(2)$ & $1.22(3)$ & C4-C5-C6 & $121.6(2)$ & $122(2)$ \\
C7-C8 & $1.493(3)$ & $1.49(4)$ & C1-C6-C5 & $116.1(2)$ & $117(1)$ \\
C9-O3 & $1.420(2)$ & $1.42(4)$ & C1-C6-C7 & $119.6(2)$ & $120(3)$ \\
C10-O2 & $1.425(2)$ & $1.42(4)$ & C5-C6-C7 & $124.2(2)$ & $122(2)$ \\
& & & O4-C7-C6 & $119.8(2)$ & $120(2)$ \\
& & & O4-C7-C8 & $116.1(2)$ & $120(2)$ \\
& & & C6-C7-C8 & $124.1(2)$ & $120(3)$ \\
& & & C3-O2-C10 & $119.0(2)$ & $118(3)$ \\
& & & C5-O3-C9 & $119.1(2)$ & $118(2)$ \\
\hline
\end{tabular}

deviations were observed to the $\mathrm{C} 18(-0.173(4) \AA)$ and C19 (0.120(4) $\AA$ ) atoms. The least squares planes of the $\mathrm{A}$ and $\mathrm{B}$ molecules form an angle of $0.8(1)^{\circ}$. This result shows that the two moieties are in the same plane, which is also illustrated in Figures 3 and 4.

The molecules A and B exhibited strong intra-molecular hydrogen bonds involving $\mathrm{O} 1-\mathrm{HO} 1 \ldots \mathrm{O} 4$ and $\mathrm{O} 5-\mathrm{HO} 5 \ldots \mathrm{O} 8$, respectively (Table 3 and Figure 1). The weak intermolecular hydrogen bond between the aromatic hydrogen linked to $\mathrm{C} 4$ (molecule $\mathrm{A}$ ) and the adjacent carboxyl oxygen $\mathrm{O} 1$ at $\mathrm{x}+1, \mathrm{y}, \mathrm{z}$ stabilizes the packing of the molecule $\mathrm{A}$ and gives rise to an infinite one dimensional chain parallel to the [100] direction (Table 3, Figures 1 and 3). The same interaction occur to the molecule $\mathrm{B}$ involving the aromatic hydrogen linked to $\mathrm{C} 14$ (molecule B) and the adjacent carboxyl oxygen $\mathrm{O} 5$ at $\mathrm{x}+1, \mathrm{y}, \mathrm{z}$. The chains form a planar structure, connected by van der Waals interactions along the [011] direction. Therefore, the chains are linked

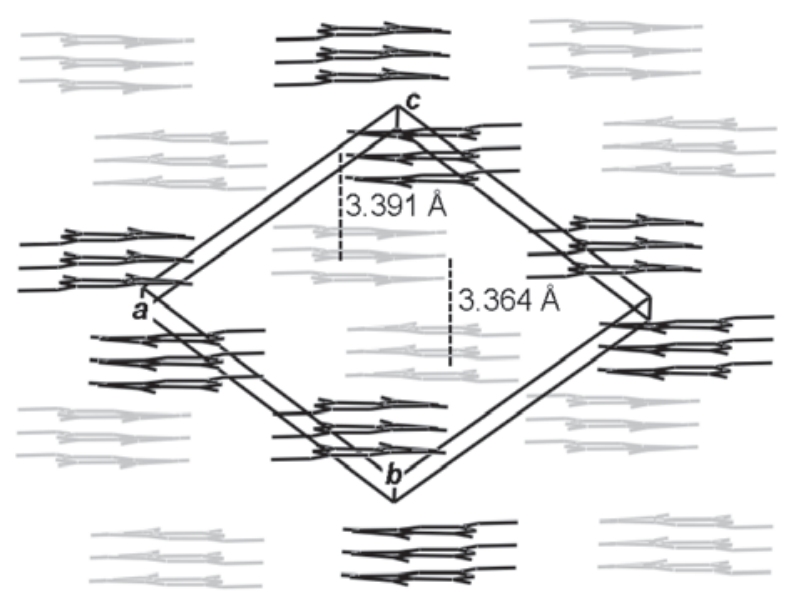

Figure 4. Packing of (1) projected onto bc plane. The separations between parallels infinite two-dimensional network parallel to the (011) plane are shown as dashed lines.

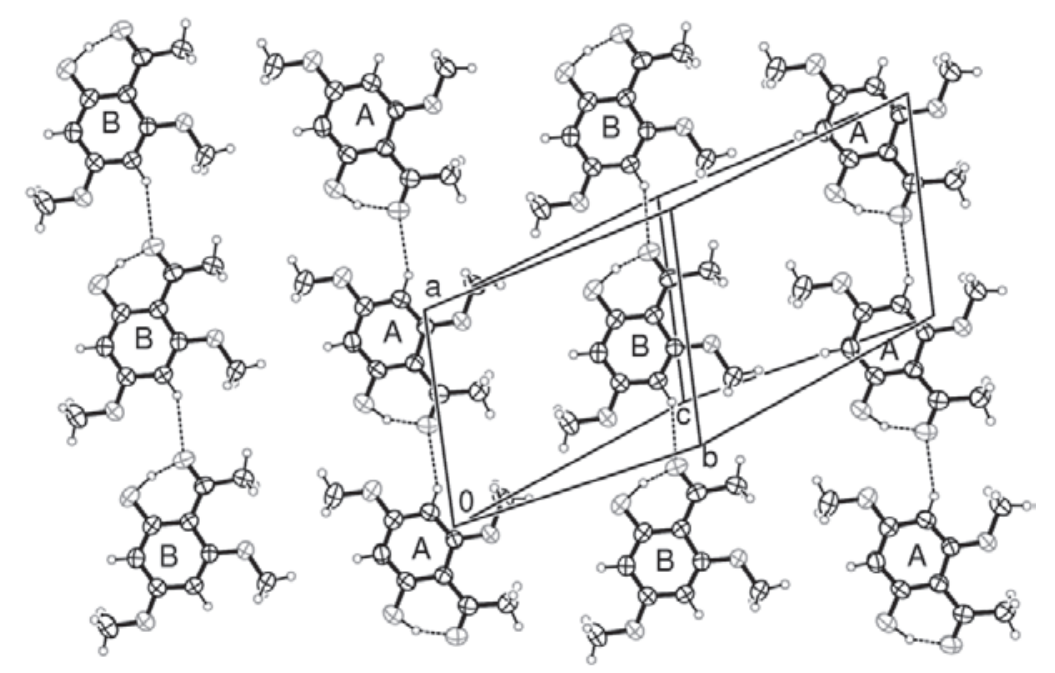

Figure 3. Packing of (1), showing the infinite two-dimensional network in the (011) plane. Hydrogen bonds are indicated by dashed lines. 
Table 3. Hydrogen-bonding geometry $\left(\AA,^{\circ}\right)$

\begin{tabular}{lllll}
\hline D-H...A & D-H & H...A & D...A & D-H...A \\
\hline O1-HO1...O4 & $1.05(3)$ & $1.53(2)$ & $2.500(3)$ & $152(3)$ \\
O5-HO5 ..O8 & $1.14(2)$ & $1.38(2)$ & $2.487(3)$ & $162(2)$ \\
C4-H4 ..O4 & 0.93 & 2.44 & $3.302(3)$ & 153 \\
C14-H14 ..O8 $^{i}$ & 0.93 & 2.46 & $3.300(3)$ & 151
\end{tabular}

iSymmetry code: $1+\mathrm{x}, \mathrm{y}, \mathrm{z}$.

themselves, forming an infinite two-dimensional network parallel to the (011) plane. The stacking of these twodimensional networks is shown in the Figure 4. It is also observed that double chains, which are related by the inversion symmetry, are formed along [100] direction either to molecule A or B. The distance between parallels twodimensional networks is about $3.4 \AA$.

\section{Acknowledgments}

The authors are grateful to CNPq and FAPESP for financial support. One of us, MGS, thanks FAPESP for the postdoctoral fellowship.

\section{Supplementary Information}

${ }^{1} \mathrm{H}$ and ${ }^{13} \mathrm{C}$ NMR data for $\mathbf{1}$ are avaliable free of charge at http://jbcs.sbq.org.br, as PDF file.

Supplementary crystallographic data sets for (1) is available through the Cambridge Structural Data Base, deposition number CCDC 296321. Copies of this information may be obtained free of charge from The Director, CCDC, 12 Union Road, Cambridge, CB2 1EZ, UK (fax: +44123-336-033; e-mail: deposit@ccdc.cam.ac.uk or http:www.ccdc.ac.uk

\section{References}

1. Salas, F. V. In Plantas Medicinales de Venezuela; Velez Boza, F., ed.; INAGRO: Caracas, 1982.

2. Mabberley, D. J.; The Plant-book. A Portable Dictionary of the Higher Plants, Cambridge University Press: New York, USA, 1997.

3. Joly, A. B.; Introdução a Taxonomia Vegetal. Editora Nacional: São Paulo, Brazil, 1985.

4. Parmar, V. S.; Jain, S. C.; Bisht, K. S.; Jain, R.; Taneja, P.; Jha, A.; Tyagi, O. D.; Prasad, A. K.; Wengel, J.; Olsen, C. E.; Bol, P.M.; Phytochemistry 1997, 46, 597.

5. Martins, R. C. C.; Lago, J. H. G.; Albuquerque, S.; Kato, M. J.; Phytochemistry 2003, 64, 667.

6. Lago, J. H. G.; Ramos, C. S.; Casanova, C. C. D.; Morandim, A. A.; Bergamo, C.D.; Cavalheiro, A. J.; Bolzani, V. S.; Furlan, M.; Guimarães, E. F.; Young, M. M. C.; Kato, M.J.; J. Nat. Prod. 2004, 67, 1783.
7. Moreira, D. L.; Guimarães, E. F.; Kaplan, M. A.; Phytochemistry 1998, 49, 1339.

8. Baldoqui, D. C.; Kato, M. J.; Bolzani, V. S.; Young, M. C. M.; Furlan, M.; Phytochemistry 1999, 51, 889.

9. Silva, R. V.; Navickiene, H. M. D.; Kato, M. J.; Bolzani, V. S.; Méda, C. I.; Young, M. C. M.; Phytochemistry 2002, 59, 521.

10. Alécio, A. C.; Bolzani, V. S.; Young, M. C. M., Furlan, M.; J. Nat. Prod, 1998, 61, 637.

11. Dodson, C. D.; Dyer, L. A.; Searcy, J.; Wright, Z.; Letourneau, D. K.; Phytochemistry 2002, 53, 51.

12. Orjala, J.; Erdelmeier, C. A. J.; Wright, A. D.; Rali, T.; Sticher, O.; Planta Med. 1993, 59, 813.

13. Facundo, V. A.; Sa, A. L.; Silva, S. A. F.; Morais, S. M.; Matos, C. R. R.; Braz, R.; J. Braz. Chem. Soc. 2004, 15, 140.

14. Danelutte, A. P.; Costantin, M. B.; Delgado, G. E.; Braz, R.; Kato, M. J.; J. Braz. Chem. Soc. 2005 , 6B,1425.

15. Salazar, K. J. M.; Paredes, G. E. D.; Lluncor, L. R.; Young, M. C. M.; Kato, M. J.; Phytochemistry 2005, 66, 573.

16. Tanaka, T.; Asai, F.; Iinuma, M.; Phytochemistry 1998, 49, 229.

17. Cheng, M. J.; Lee, S. J.; Chang, Y. Y.; Wu, S. H.; Tsai, I. L.; Jayaprakasam, B.; Chen, I. S.; Phytochemistry 2003, 63, 603.

18. Bayma, J. C.; Arruda, M. S. P; Müller, A. H.; Arruda, A. C.; Canto, W. C. C.; Phytochemistry 2000, 55, 779.

19. Monache, F. D.; Compagnone, R. S.; Phytochemistry 1996, 43, 1097.

20. Sala, A.; Recio, M. C.; Giner, R. M.; Màñez, S.; Ríos, J. L.; J. Nat. Prod. 2001, 64, 1360.

21. Favier, L.; Tonn, C.; Guerreiro, E.; Rotelli, A.; Pelzer, L.; Planta Med. 1998, 64, 657.

22. Huang, P.; Won, S.; Day, S.; Lin, C.; Helv. Chim. Acta 1999, 82, 1716.

23. Suksamrarn, A.; Eiamong, S.; Piyachaturawat, P.; Byrnes L.T.; Phytochemistry 1997, 45, 103.

24. Saxena, S.; Jain, D. C.; J. Ind. Chem. Soc. 2002, 79, 970.

25. Rustaiyan, A.; Zare, K.; Gangi, M. T.; Sadri, H. A.; Phytochemistry 1989, 28, 1535.

26. Lorimer, S.D.; Perry, N.B; Planta Med. 1994, 60, 386.

27. Astudillo, L.; Schmeda-Hirschmann, G.; Soto, R.; Sandoval, C.; Afonso, C.; Gonzales, M. J.; Kijjoa, A.; World J. Microbiol. Biotechnol. 2000, 16, 585.

28. Goldoni, L.; Cravorro, G.; Penoni, A.; Tollari, S.; Palmsano, G.; Synlett 2005, 6927.

29. Cunningham, B. D. M.; Lowe, P. R.; Threadgill, M. D.; J. Chem. Soc. 1989, 9, 1275.

30. Kawadias, D.; Sand, P.; Youndim, K. A.; Qaiser, M. Z.; RiceEvans, C.; Baur, R.; Sigel, E.; Rausch, W. D.; Riederer, P.; Schreier, P.; Br. J. Pharmacol. 2004, 142, 811.

31. Matieva, N. N.; Rao, N.; Redda, K. K.; J. Heterocycl. Chem. 2002, 39, 1251.

32. Nonius, Collect Software, Delft, The Netherlands, 1998

33. Otwinowski, Z.; Minor, W; Methods Enzymol. 1997, 276, 307. 
34. Sheldrick, G. M.; SHELXS-97 and SHELXL-97; Program for Crystal Structure Refinement, University of Göttingen: Germany, 1997.

35. Farrugia, L. J.; J. Appl. Crystallogr. 1997, 30, 565.

36. Farrugia, L.J.; J. Appl. Crystallogr. 1999, 32, 837.

37. Bruno, I. J.; Cole, J. C.; Edgington, P. R.; Kessler, M. K.; Macrae, C. F.; McCabe, P.; Pearson, J.; Taylor, R.; Acta Crystallogr., Sect. B: Struct. Sci. 2002, 58, 389.

38. Kabsch, W.; Acta Crystallogr., Sect. A: Found. Crystallogr. 1976, 32, 922.
39. Spek A.L.; PLATON, A Multipurpose Crystallographic Tool, Utrecht University: Utrecht, The Netherlands, 2005.

40. Bruno, I. J.; Cole, J. C.; Kessler, M.; Luo, J.; Motherwell, W. D. S.; Purkis, L. H.; Smith, B. R.; Taylor, R.; Cooper, R. I.; Harris S. E.; Orpen, A. G.; J. Chem. Inf. Comput. Sci. 2004, 44, 2133.

41. Allen, F. H.; Acta Crystallogr., Sect. B: Struct. Sci. 2002, 58, 380.

Received: January 31, 2006

Published on the web: July 20, 2006

FAPESP helped in meeting the publication costs of this article. 


\section{2-Hydroxy-4,6-dimethoxyacetophenone from Leaves of Peperomia glabella}

Marisi G. Soares, ${ }^{a}$ Ana P. V. de Felippe, ${ }^{a}$ Elsie F. Guimarães, ${ }^{a}$ Massuo J. Kato, ${ }^{a}$ Javier Ellena ${ }^{b}$ and Antonio C. Doriguetto ${ }^{*, c}$

${ }^{a}$ Instituto de Química, Universidade de São Paulo, Av. Prof. Lineu Prestes, 748, Cidade Universitária, 05508-900 São Paulo-SP, Brazil

${ }^{b}$ Instituto de Física de São Carlos, Universidade de São Paulo, CP 369, 13560-970 São Carlos-SP, Brazil

${ }^{c}$ Departamento de Ciências Exatas, Universidade Federal de Alfenas, 37130-000 Alfenas-MG, Brazil

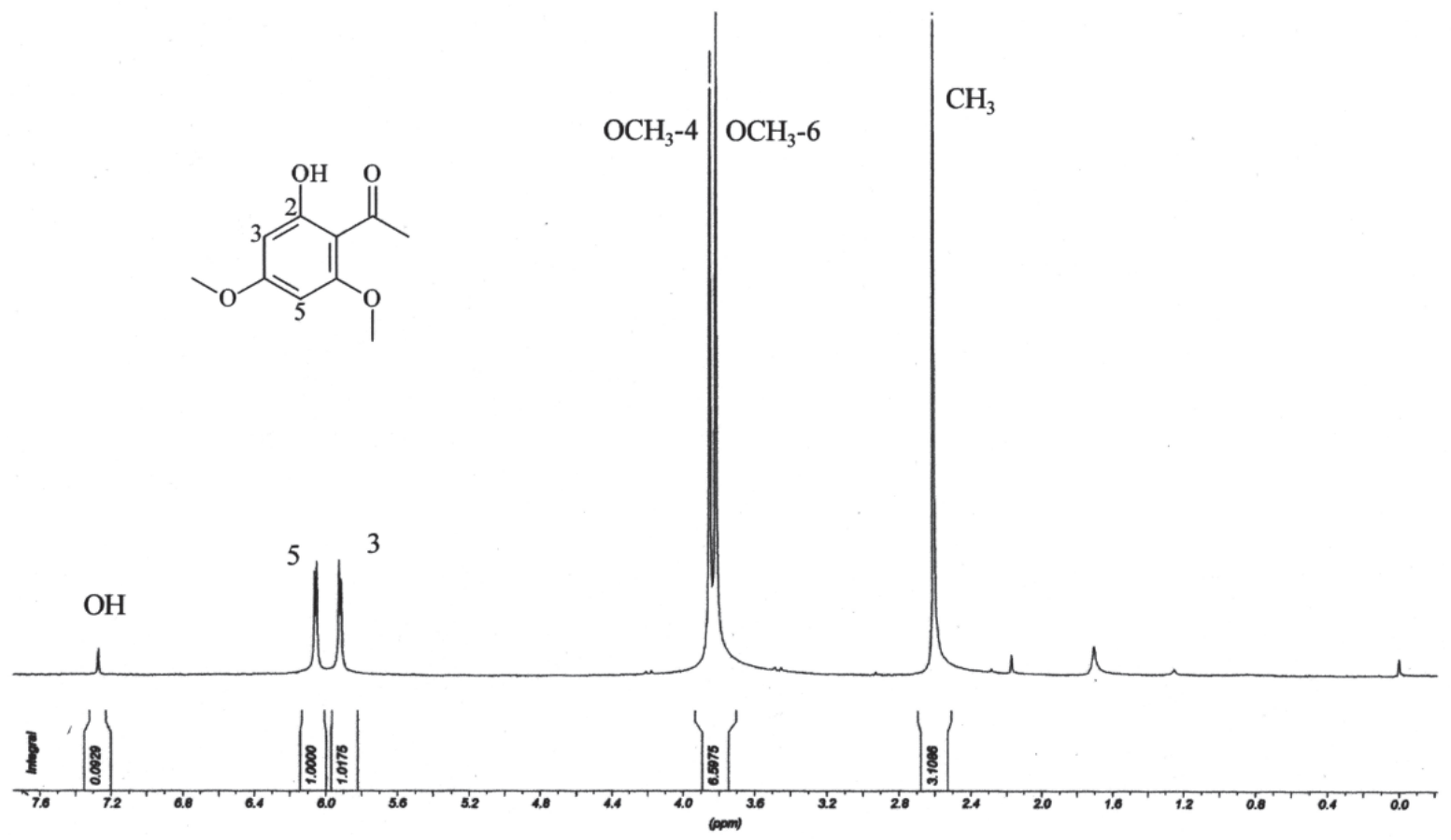

Figure S1. ${ }^{1} \mathrm{H}$ NMR spectra of (1) (4.9 T). 


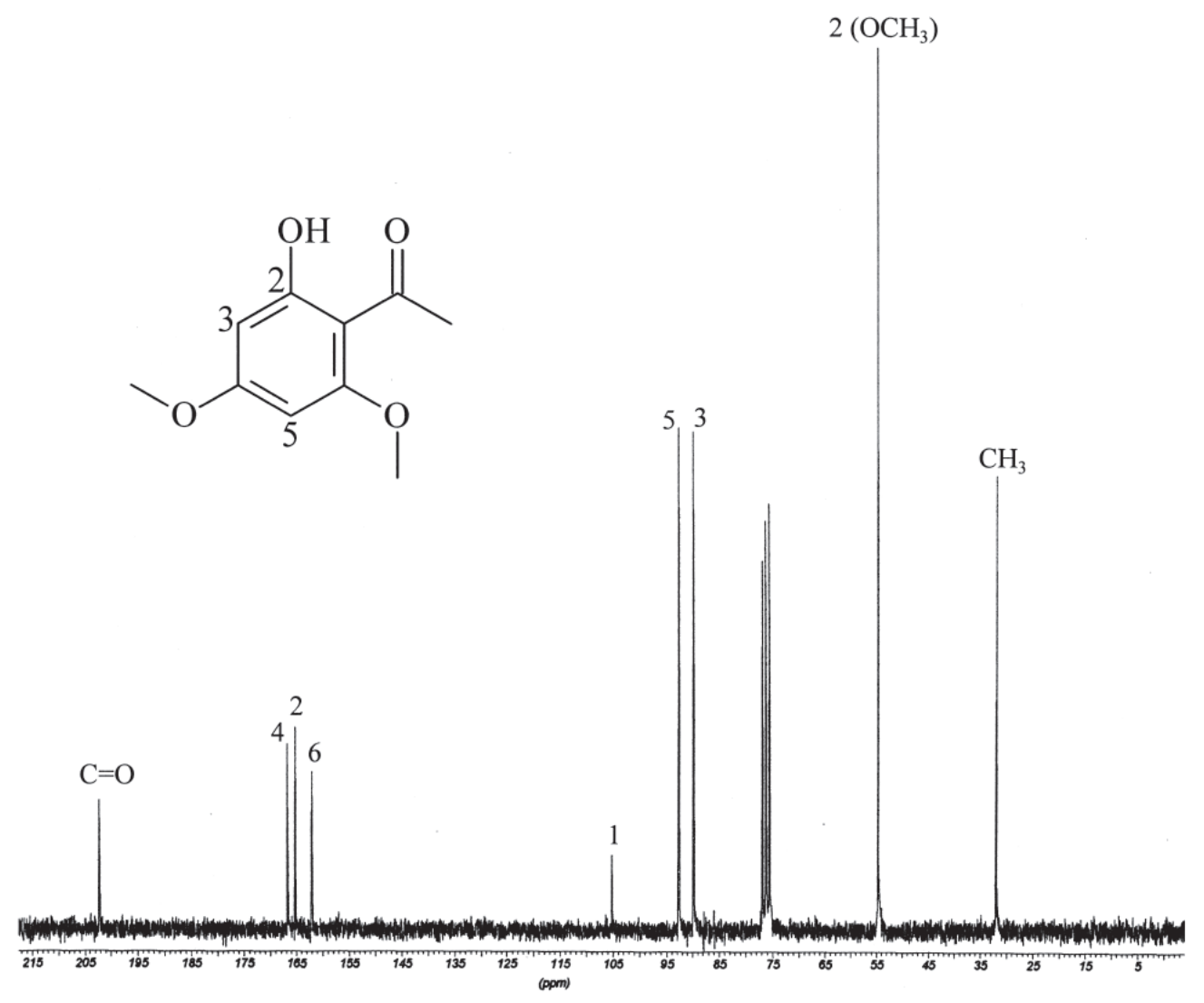

Figure S2. ${ }^{13} \mathrm{C}$ NMR spectra of (1) (4.9 T). 